\title{
PENGARUH STRATEGI PEMBELAJARAN DAN GAYA BELAJAR SISWA TERHADAP HASIL BELAJAR MATEMATIKA SISWA
}

\author{
Winner Macson Pandiangan ${ }^{1}$, Sahat Siagian ${ }^{2}$, Harun Sitompul \\ ${ }^{1}$ Sekolah Menengah Kejuruan Pharmaca Medan, Sumatera Utara, \\ ${ }^{2,3}$ Program Pascasarjana Universitas Negeri Medan \\ 1'winnermacsonpandingan@gmail.com, ${ }^{2}$ sahat.sgn61@gmail.com, ${ }^{3}$ prof_runsit@yahoo.co.id
}

\begin{abstract}
Abstrak: Penelitian ini bertujuan untuk mengetahui: (1) perbedaan hasil belajar Matematika antara siswa yang dibelajarkan dengan menggunakan Strategi TGT dan Strategi Ekspositori, (2) mengetahui perbedaan hasil belajar siswa yang memiliki Gaya Belajar Kinestetik dan Gaya Berpikir Visual (3) interaksi antara penggunaan Strategi pembelajaran dan Gaya belajar dalam mempengaruhi hasil belajar Matematika siswa. Populasi penelitian ini adalah siswa kelas XI SMK Pharmaca Medan sebanyak 3 kelas dengan jumlah 122 orang. Teknik penarikan sampel dilakukan dengan cluster random sampling. Metode penelitian menggunakan metode quasi eksperimen dengan disain penelitian faktorial $2 \times 2$, sedangkan teknik analisis data menggunakan ANAVA dua jalur pada taraf signifikansi $\alpha=0.05$. Syarat ANAVA adalah data berdistribusi normal dengan Lilifors dan data harus memiliki varians populasi homogen dengan uji Bartlett dan uji Fisher. Hasil penelitian diperoleh: (1) hasil belajar Matematika siswa yang dibelajarkan dengan menggunakan Strategi Pembelajaran TGT lebih tinggi dibandingkan dengan menggunakan Strategi Ekspositori, (2) hasil belajar Matematika siswa yang memiliki Gaya belajar Kinestetik lebih tinggi dibandingkan dengan Gaya belajar Visual dan (3) terdapat interaksi antara penggunaan Strategi pembelajaran dengan Gaya belajar dalam mempengaruhi hasil belajar Matematika.
\end{abstract}

Kata Kunci: strategi pembelajaran, gaya belajar, hasil belajar matematika

Abstract: This study aims to determine: (1) differences in mathematics learning outcomes between students who are taught using the TGT Strategy and Expository Strategy, (2) knowing the differences in learning outcomes of students who have Kinesthetic Learning Styles and Visual Thinking Styles (3) interactions between uses Learning strategies and learning styles in influencing students' mathematics learning outcomes. The population of this study were 3 class students of Pharmaca Medan Vocational High School as many as 3 classes with a total of 122 people. The sampling technique was carried out by cluster random sampling. The research method uses a quasi-experimental method with $2 \times 2$ factorial research design, while the data analysis technique uses two-way ANOVA at a significance level $\alpha=0.05$. ANOVA requirements are normally distributed data with Lilifors and data must have homogeneous population variance with the Bartlett test and Fisher's test. The results of the study were obtained: (1) the students 'mathematics learning outcomes that were learned using the TGT Learning Strategy were higher than using the Expository Strategy, (2) the students' mathematics learning outcomes who had a Kinesthetic Learning Style were higher than the Visual learning styles and (3) there were interaction between the use of learning strategies and learning styles in influencing mathematics learning outcomes.

Keywords: learning strategies, learning styles, mathematics learning outcomes

\section{PENDAHULUAN}

Matematika sesungguhnya merupakan mata pelajaran yang melatih siswa berpikir kritis, kreatif, berpikir alternatif, berargumentasi ketat, menyatakan buah pikirannya baik dalam lisan maupun tulisan secara sistematis, logis, dan lugas. Dalam matematika juga dapat diajarkan pola berpikir deduktif dan induktif. Hal ini berarti bahwa pada batas tertentu matematika perlu dikuasai oleh segenap warga negara Indonesia karena metematika mampu memberikan bekal penataan nalar dan pembentukan sikap mental. Untuk hal tersebut, maka perlu memerhatikan 
daya imajinasi dan rasa ingin tahu dari anak didik. Siswa harus dibiasakan untuk diberi kesempatan bertanya dan berpendapat sehingga diharapkan proses pembelajaran matematika lebih bermakna.

Kemudian dalam domain Sekolah Menengah Kejuruan (SMK) khususnya SMK Farmasi Matematika mempunyai peran yang sangat penting dalam mendukung terhadap mata pelajaran produktif yang membutuhkan kemampuan-kemampuan yang didapat dalam mata pelajaran Matematika. Dalam mencapai tujuan dari mata pelajaran tersebut guru yang efektif harus senantiasa mengasah kemampuan ilmiah dan pedagogik yang diimplementasikan dalam pengajaran di kelas melalui strategi pembelajaran melalui pendekatan teacher centered dan pendekatan student centered.

Metode diskusi merupakan salah satu bentuk pendekatan student centered dengan cara mendidik yang berupaya memecahkan masalah yang dihadapi, baik dua orang atau lebih yang masing - masing mengajukan argumentasinya untuk memperkuat pendapatnya. Untuk mendapatkan hal yang disepakati, tentunya masing - masing menghilangkan perasaan subjektivitas dan emosionalitas yang akan mengurangi bobot pikir dan pertimbangan akal yang semestinya. (Majid, 2008:141)

Proses pembelajaran atau pengajaran kelas (Classroom Teaching) menurut Dunkin dan Biddle (1974:38) berada pada empat variabel interaksi yaitu (1) variabel pertanda (presage variables) berupa pendidik; (2) variabel konteks (context variables) berupa peserta didik, sekolah, masyarakat; (3) variabel proses (process variables) berupa interaksi peserta didik dengan pendidik; dan variabel produk (product variable) berupa perkembangan peserta didik dalam jangka pendek maupun jangka panjang. Proses pembelajaran akan berlangsung dengan baik jika pendidik mempunyai dua kompetensi utama yaitu; (1) kompetensi substansi materi pembelajaran atau penguasaan materi pembelajaran, dan (2) kompetensi metodologi pembelajaran. Artinya jika guru menguasai materi pembelajaran diharuskan juga menguasai metode pengajaran sesuai kebutuhan materi ajar yang mengacu pada prinsip pedagogik yaitu memahami karakteristik siswa, jika metode dalam pembelajaran tidak dikuasai, maka penyampaian materi ajar menjadi tidak maksimal (Sagala 2008 : 63)

Salah satu masalah dalam proses pembelajaran yang dikembangkan guru dewasa ini adalah proses pembelajaran yang terjadi di dalam kelas dilaksanakan sesuai kemampuan dan selera guru. Pada kenyataannya kemampuan guru tidak merata sesuai dengan latar belakang pendidikan guru serta motivasi dan kecintaan mereka terhadap profesinya. Ada guru yang dalam melaksanakan pengelolaan pembelajaran dilakukan dengan sungguh-sungguh melalui perencanaan yang matang dengan memanfaatkan sumber daya yang ada dan memperhatikan taraf perkembangan intelektual dan perkembangan psikologi siswa. Guru yang demikian akan dapat menghasilkan kualitas lulusan yang lebih tinggi dibandingkan dengan guru yang dalam pengelolaan pembelajaran dilakukan seadanya tanpa mempertimbangkan berbagai faktor yang mempengaruhi keberhasilan proses pembelajaran. Oleh sebab itu untuk mencapai standar proses pendidikan sebaiknya dimulai dengan menganalisis komponen guru (Sanjaya, $2006: 5$ ).

\section{Strategi Pembelajaran kooperatif Tipe TGT}

Falsafah yang mendasari strategi pembelajaran kooperatif atau gotong royong dalam pendidikan adalah falsafah homo homini spcius. Falsafah ini menekankan bahwa manusia adalah makhluk sosial. Kerja sama merupakan kebutuhan yang sangat penting artinya bagi kelangsungan hidup. Tanpa kerja sama, tidak akan ada individu, keluarga, organisasi, atau sekolah. Tanpa kerja sama, kehidupan ini sudah punah (Lie, 2008:28).

Menurut Sanjaya (2008:240) dilihat dari landasan psikologi belajar, pembelajaran kelompok banyak dipengaruhi oleh psikologi kognitif holistik yang menekankan bahwa belajar pada dasarnya adalah proses berfikir. Namun demikian, psikologi humanistik juga mendasari pembelajaran ini. Dalam pembelajaran kelompok pengembangan kemampuan kognitif harus diimbangi dengan perkembangan interpersonal. Teori medan, misalnya yang bersumber dari aliran psikologi kognitif atau psikologi Gestalt, menjelaskan bahwa keseluruhan lebih memberi makna dari pada bagian-bagian terpisah.

Lebih lanjut dinyatakan bahwa Ekwal dan Shanker dalam Ginnis (2008:28) 
menemukan bahwa orang pada umumnya dapat mengingat tentang: (1) $10 \%$ dari apa yang mereka baca, (2) $20 \%$ dari apa yang mereka dengarkan, (3) 30\% dari apa yang mereka lihat, (4) $50 \%$ dari apa yang mereka lihat dan dengarkan, (5) $70 \%$ dari apa yang mereka ucapkan, (6) $90 \%$ dari apa yang mereka ucapkan dan dilakukan bersama-sama.

Oleh karena itu untuk memaksimalkan belajar, buat belajar aktif dengan cara episodik. Bila memungkinkan, perlu dirancang aktifitas yang melibatkan siswa dalam kegiatan fisik selain berbicara, mendengarkan, membaca dan melihat. Ciptakan pengalaman belajar yang benar-benar adalah pengalaman. Belajar episodik itu mudah, hal ini berlangsung sepanjang waktu secara alamiah. Sebaliknya, pengingatan semantik membutuhkan sangat banyak motivasi internal, dipicu sendiri oleh bahasa, dan adalah hal yang paling lemah dalam system pengingatan karena dalam masa evolusi yang sangat lama, semantik merupakan yang paling akhir berkembang.

Salah satu strategi pembelajaran kelompok adalah strategi pembelajaran kooperatif. Cooperative learning mengandung pengertian bekerja sama dalam mencapai tujuan bersama. Dalam kegiatan kooperatif siswa secara individual mencari hasil yang menguntungkan bagi seluruh anggota kelompoknya (Hasan, 1996). Di lain pihak, Slavin (1984) menyatakan bahwa cooperative learning adalah suatu strategi pembelajaran yang mengarahkan siswa belajar dan bekerja sama dalam bentuk kelompok tersebut. Lebih lanjut Slavin juga menyatakn bahwa cooperative learning adalah suatu strategi pembelajaran bagi siswa untuk belajar dan bekerja dalam kelompok-kelompok kecil secara kolaboratif yang anggotanya terdiri dari 4 sampai 5 orang dengan struktur kelompoknya yang bersifat heterogen.

Salah satu kendala yang mungkin dihadapi guru dalam hal pengelompokkan heterogen adalah keberatan dari pihak siswa yang berkemampuan akademis tinggi. Siswa dari kelompok ini bisa merasa "rugi" dan dimanfaatkan tanpa bisa mengambil manfaat apa-apa dalam kegiatan belajar cooperative learning karena rekan-rekan mereka dalam kelompok tidak lebih pandai dari mereka.

Lie (2008:29) menyatakan strategi pembelajaran cooperative learning tidak sama dengan sekedar belajar kelompok. Ada unsurunsur dasar pembelajaran cooperative learning yang membedakan dengan pembagian kelompok yang dilakukan asal-asalan. Pelaksanaan prosedur strategi pembelajaran cooperative learning dengan benar akan memungkinkan pendidikan mengelola kelas dengan lebih efektif.

Masih di dalam Lie, Roger dan Johnson menyatakan lima unsur strategi pembelajaran gotong-royong yang harus diterapkan untuk mencapai hasil yang optimal yaitu (1) saling ketergantungan positif, (2) tanggung jawab perseorangan, (3) tatap muka, (4) komunikasi antaranggota, dan (5) evaluasi proses kelompok. Secara hakikat, siswa sebenarnya telah memiliki bekal pengetahuan, keterampilan, dan motivasi yang berbeda. Keragaman tersebut berpengaruh pada pelaksanaan pembelajaran. Bagi siswa yang memiliki kesiapan (konsep, keterampilan, motivasi, serta minat) akan memberi sinergi yang baik dalam proses terjadinya pembelajaran. Kenyataan dalam pembelajaran menunjukkan bahwa ada siswa yang dapat menyerap pembelajaran dengan cepat, sedang dan lambat. Salah satu strategi pembelajaran yang cukup relevan dengan mata pelajaran matematika adalah strategi pembelajaran kooperatif tipe TGT (Team Games Turnament).

\section{Strategi Pembelajaran Ekspositori}

Pembelajaran ekspositori adalah pembelajaran yang menekankan kepada proses penyampaian materi secara verbal dan seorang guru kepada sekelompok siswa dengan maksud agar siswa dapat menguasai materi pelajaran secara optimal. Roy Killen (1998) menamakan strategi ekspositori ini dengan istilah pembelajaran langsung (direct instruction).

Teori belajar yang mendasari strategi pembelajaran ekspositori adalah teori belajar bevavioristik. Perubahan tingkah laku terjadi sebagai akibat interaksi stimulus dan respon. Dengan kata lain belajar adalah perubahan yang dialami oleh siswa dalam hal kemampuannya untuk bertingkah laku dengan cara yang baru sehingga hasil interaksi antara stimulus dan respon.

Menurut Discroll ( 1993 ) bahwa pada dasarnya pembelajaran ekspositori sama dengan pembelajaran yang terjadi dengan belejar menerima. Toeri behavoristik juga cenderung mengarahkan siswa untuk berpikir linier dan konvergen.

Adapun karakteristik pembelajaran ekspositori: (1) dilakukan dengan cara 
menyampaikan materi pelajaran secara verbal; (2) biasanya materi yang disampaikan adalah materi yang sudah jadi, seperti data atau fakta, konsep-konsep tertentu yang harus dihafal sehingga tidak menuntut siswa untuk berpikir ulang; (3) Tujuan utama pembelajaran adalah penguasaan materi pelajaran.

Makmun (2003 : 233) yang dikutip oleh Sagala (2007: 79) menyatakan bahwa dalam pembelajaran dengan pendekatan ekspositori guru menyajikan bahan dalam bentuk yang telah dipersiapkan secara rapi, sistematik dan lengkap sehingga siswa tinggal menyimak dan mencernanya secara teratur dan tertib".

Sanjaya (2007:177) menyatakan "beberapa langkah dalarn penerapan pembelajaran ekspositori: 1) persiapan (preparation) yaitu berkaitan dengan mempersiapkan siswa untuk rnenerima pelajaran: (2) penyajian (Presentation) berkaitan dengan penyarnpaian materi pelajaran sesuai dengan persiapan telah dilakukan; (3) menghubungkan (corelation) berkaitan dengan menghubungkan materi pelajaran dengan pengalajaran siswa atau hal-hal lain yang siswa dapat merangkap keterkaitannya dalam struktur pengetahuan yang telah dimilikinya; (4) rnenyirnpulkan (generalization) berkaitan dengan memahami inti (core) dan materi pelajaran yang telah disajikan; mengaplikasikan (Aplication) berkaitan dengan langkah unjuk kemampuan siswa setelah menyimak penjelasan guru".

\section{Gaya Belajar Kinestetik}

Gaya Belajar Kinestetik Ciri-ciri perilaku yang merupakan petunjuk bagi individu yang memiliki gaya belajar secara Kinestetik (DePorter, 2007:168): 1) berbicara dengan lambat 2) terbiasa menyentuh orang lain untuk mendapatkan perhatian 3)terbiasa berdiri dekat-dekat dengan lawan bicara 4) Berorientasi pada fisik dan banyak bergerak 5) belajar melalui mampulasi dan praktek 6) terbiasa menghafal denan berjalan dan melihat 7) membaca dengan-menggunakan jari untuk menunjuk 8) banyak menggunakan isyarat tubuh 9) tidak dapat duduk dengan tenang pada waktu yang lama 10) membuat keputusan berdasarkan perasaan 11) kebiasaan mengetukngetuk pena, jari, atau kaki saat mendengarkan 12) banyak meluangkan waktu untuk berolah raga dan kegiatan fisik lainnya.

Siswa dengan tipe kinestetik lebih menyukai proyek terapan. Lakon pendek dan lucu terbukti dapat membantu siswa kinestetik dapat belajar melalui gerakan, dan paling baik menghafal informasi dengan mengasosiasikan gerakan dengan setiap fakta. Tunjukkan caranya kepada mereka. Banyak siswa kinestetik menjauhkan diri dari bangku, mereka lebih suka duduk dilantai dan menyebarkan pekerjaan di sekeliling mereka. individu yang memiliki kemampuan belajar kinestetik yang baik ditandai dengan ciri-ciri perilaku sebagai berikut: berbicara dengan perlahan, menanggapi perhatian fisik, menyentuh orang lain untuk mendapatkan perhatian mereka, berdiri dekat ketika sedang berbicara dengan orang lain, belajar melalui praktek langsung atau memanipulasi, menghafalkan sesuatu dengan cara berjalan atau melihat langsung, menggunakan jari-jari untuk menunjuk kata yang dibaca ketika sedang membaca, banyak menggunakan bahasa tubuh (non verbal), tidak dapat duduk diam disuatu tempat untuk waktu yang lama, sulit membaca peta kecuali ia memang pernah ketempat tersebut, menggunakan kata-kata yang aksi, pada umumnya tulisannya jelek, menyukai kegiatan atau permainan yang menyibukkan (secara fisik) dan ingin melakukan segala sesuatu.

\section{Gaya Belajar Visual}

Gaya Belajar Visual adalah Individu yang memiliki gaya belajar visual yang baik ditandai dengan ciri-ciri perilaku sebagai berikut, DePorter (2000:116): 1) rapi dan teratur 2) berbicara dengan cepat 3) mampu membuat rencana jangka pendek dengan baik 4) teliti dan rinci 5) mementingkan penampilan 6) lebih mudah mengingat apa yang akan dilihat daripada apa yang didengar 7) mengingat sesuatu berdasarkan asosiasi visual 8) memiliki kemampuan mengeja huruf dengan sangat baik 9) biasanya tidak mudah terganggu oleh keributan atau suara berisik ketika sedang belajar 10) sulit menerima instruksi verbal (oleh karena itu seringakali minta instruksi secara tertulis 11) merupakan pembaca yang cepat dan tekun 12) lebih suka membaca daripada dibacakan 13) suka membuat coretan-coretan tanpa arti ketika sedang bertelepon atau menghadiri rapat 14) lebih suka mendemontrasikan sesuatu dan pada berpidato/berceramah 15) lebih tertarik pada bidang seni (lukisan, pahat, gambar) dari pada musik, dan 16) sering tahu apa yang dikatakan, tetapi tidak pandai menuliskan dalam kata-kata. 
Gaya belajar visual dapat diketahui oleh guru melalui gerakan mata dan mendengarkan pembicaraan mereka. Jika siswa duduk tegak dan melihat lurus ke depan atau yang matanya memandang ke atas saat menerima informasi, dan berbicara cepat. Cara belajar yang dianjurkan bagi tipe visual saat mengikuti pelajaran ialah dengan makalah, hand out, atau buku referensi yang bisa mendukung. Bila siswa tipe ini termasuk orang yang mudah menghafal tulisan sendiri, sebaiknya membuat catatan sendiri. Selalu siap dengan pulpen dan kertas catatan untuk mencatat. Membuat catatan dengan membuat skema, bagan, grafik dan bentuk pemetaan visual lainnya dan materi bahan yang dipelajari akan dapat membantu siswa tipe visual. Penguatan catatan atau alat bantu belajar dengan memberi warna dan gambar.

Dirumuskan permasalahan penelitian sebagai berikut :

1. Apakah hasil belajar matematika kelompok siswa yang diajari dengan menggunakan strategi pembelajaran kooperatif tipe TGT lebih tinggi dari kelompok siswa yang diajar dengan menggunakan strategi pembelajaran Ekspositori?

2. Apakah hasil belajar matematika kelompok siswa yang memiliki gaya belajar kinestetik lebih tinggi daripada hasil belajar siswa yang memiliki gaya belajar visual?

3. Apakah ada interaksi antara strategi pembelajaran dan gaya belajar dalam mempengaruhi hasil belajar matematika?

\section{METODE}

Penelitian ini dilakukan di SMK Pharmaca Medan. Populasi dalam penelitian ini adalah seluruh siswa kelas XII SMK Pharmaca Medan. terdiri dari 3 kelas dengan jumlah siswa 122 orang. Untuk menentukan kelas sampel maka digunakan teknik pengambilan sampel kelompok secara acak (cluster random sampling). Kelas sampel yang digunakan sebanyak 2 kelas eksperimen. Dua kelas tersebut akan diberi perlakuan yaitu : Kelas XI A : Kelas yang dibelajarkan dengan menggunakan strategi pembelajaran Koperatif tipe TGT. Kelas XI B : Kelas yang dibelajarkan dengan menggunakan strategi pembelajaran ekspositori. Setiap kelas memiliki karakteristik yang sama, artinya siswa setiap kelas memiliki umur yang tidak jauh berbeda, tidak memiliki siswa yang pernah tinggal kelas dan menggunakan kurikulum yang sama dan buku pegangan belajar yang sama. Pembagian kelas tidak berdasarkan rangking, artinya tidak ada kelas unggulan.

Metode yang digunakan pada penelitian ini adalah quasi eksperimen dengan disain faktorial $2 \times 2$. Penelitian disain faktorial mempunyai dua variabel bebas dan satu variabel terikat.

Metode quasi eksperimen dilakukan terhadap dua kelompok yang diambil dari populasi dengan dua sampel terpisah. Satu kelompok sampel dengan menggunakan strategi pembelajaran ekspositori, yang lainnya diberi dengan menggunakan strategi pembelajaran kooperatif tipe TGT. Kemudian dalam penelitian ini dilakukan pengukuran untuk mengetahui gaya belajar siswa dan hasil belajar matematika siswa dengan strategi pembelajaran ekspositori dan strategi pembelajaran kooperatif tipe TGT

Penelitian ini menggunakan desain atau rancangan faktorial $2 \times 2$. Melalui desain ini akan dibandingkan pengaruh antara strategi pembelajaran kooperatif tipe TGT dan pembelajaran ekspositori terhadap hasil belajar matematika ditinjau dari gaya belajar siswa. Untuk lebih jelas desain penelitian ini dapat dilihat pada Tabel 1 di bawah ini :

Tabel 1. Matrik Rancangan Penelitian

\begin{tabular}{|c|c|c|}
\hline Gaya & \multicolumn{2}{|c|}{ Strategi Pembelajaran (A) } \\
\hline $\begin{array}{l}\text { Belajar } \\
\text { (B) }\end{array}$ & $\begin{array}{c}\text { Kooperatif tipe } \\
\text { TGT (A1) }\end{array}$ & $\begin{array}{l}\text { Ekspositori } \\
\text { (A2) }\end{array}$ \\
\hline $\begin{array}{l}\text { Kinestetik } \\
\text { (B1) }\end{array}$ & A1B1 & A2B1 \\
\hline $\begin{array}{l}\text { Visual } \\
\text { (B2) }\end{array}$ & A1B2 & A2B2 \\
\hline
\end{tabular}

Keterangan :
A : Strategi Pembelajaran
B : Gaya Belajar
A1 : Strategi Pembelajaran kooperatif tipe
TGT
A2 : Strategi Pembelajaran (ekspositori)
B1 : Gaya Belajar Kinestetik
B2 : Gaya Belajar Visual

A1B1 : Hasil belajar matematika siswa yang diajar dengan strategi pembelajaran kooperatif tipe TGT pada siswa yang memiliki gaya belajar Kinestetik

A1B2 : Hasil belajar matematika siswa yang diajar dengan strategi pembelajaran kooperatif tipe TGT pada siswa yang memiliki gaya belajar Visual 
A2B1 : Hasil belajar matematika siswa yang diajar dengan strategi pembelajaran ekspositori pada siswa yang memiliki gaya belajar Kinestetik

A2B2 : Hasil belajar matematika siswa yang diajar dengan strategi pembelajaran ekspositori pada siswa yang memiliki gaya belajar Visual

Teknik analisis data yang digunakan adalah teknik statistik deskriptif dan inferensial. Teknik deskriptif digunakan untuk mendeskripsikan data, antara lain : nilai ratarata (mean), median, modus, standart deviasi (sd). Teknik statistik inferensial digunakan untuk menguji hipotesis penelitian, dimana teknik inferensial yang digunakan adalah teknik Analisis Varians Dua Jalur (desain faktorial 2x2) dengan taraf signifikan 0,05 (Sudjana, 2002). Dalam menggunakan ANAVA dua jalur, dilakukan uji normalitas dengan menggunakan uji Liliefors, uji homogenitas varians dengan menggunakan uji Fisher dan uji homogenitas antar varians kelompok dengan uji Bartlett. Uji lanjut terhadap interaksi antar variabel menggunakan uji Scheffe karena jumlah subjek penelitian tiap sel berbeda.

Selanjutnya untuk keperluan pengujian hipotesis, dirumuskan hipotesis statistik sebagai berikut : a. Hipotesis Pertama

$\mathrm{H}_{0}: \mu \mathrm{A}_{1} \leq \mu \mathrm{A}_{2}$

$H_{\alpha}: \mu A_{1}>\mu A_{2}$

b. Hipotesis Kedua

$\mathrm{H}_{\mathrm{o}}: \mu \mathrm{B}_{2} \leq \mu \mathrm{B}_{1}$

$\mathrm{H} \alpha: \mu \mathrm{B}_{2}>\mu \mathrm{B}_{1}$

c. Hipotesis Ketiga

$\mathrm{H}_{0}: \mathrm{A}$ X B $=0$

$\mathrm{H}_{\alpha}: \mathrm{A} X \mathrm{~B} \neq 0$

Keterangan :

$\mu \mathrm{A}_{1}$ : Hasil belajar yang diperoleh siswa dengan strategi pembelajaran kooperatif TGT

$\mu \mathrm{A}_{2}$ : Hasil belajar yang diperoleh siswa dengan strategi pembelajaran Ekspositori

$\mu B_{1}$ : Hasil belajar yang diperoleh siswa yang memiliki gaya belajar Kinestetik

$\mu B_{2}$ : Hasil belajar yang diperoleh siswa yang memiliki gaya belajar Visual

\section{HASIL PENELITIAN}

Deskripsi data yang disajikan dalam penelitian terdiri dari skor hasil belajar Matematika dengan menggunakan Strategi Pembelajaran Koperatif TGT dan skor hasil belajar Matematika dengan menggunakan Strategi Pembelajaran Eksposirori yang dikelompokkan atas gaya belajar Visual dan Kinestetik.

Tabel 2. Data Hasil Belajar Matematika Siswa

\begin{tabular}{|c|c|c|c|c|}
\hline \multirow[t]{2}{*}{ Gaya Belajar (B) } & \multicolumn{3}{|c|}{ Strategi Pembelajaran (A) } & \multirow[t]{2}{*}{ TOTAL } \\
\hline & & & $\operatorname{EKS}\left(\mathrm{A}_{2}\right)$ & \\
\hline \multirow{4}{*}{$\operatorname{Kinestetik}\left(\mathbf{B}_{1}\right)$} & $\mathrm{N}$ & 23 & 16 & 39 \\
\hline & $\Sigma X$ & 749 & 452 & 1177 \\
\hline & $\Sigma X^{2}$ & 24609 & 12904 & 36181 \\
\hline & $\overline{\boldsymbol{X}}$ & 32.56 & 28.25 & 29.66 \\
\hline \multirow[t]{4}{*}{ Visual $\left(\mathbf{B}_{2}\right)$} & $\mathrm{N}$ & 18 & 24 & 42 \\
\hline & $\Sigma X$ & 453 & 665 & 1118 \\
\hline & $\Sigma X^{2}$ & 12533 & 18671 & 30204 \\
\hline & $\bar{X}$ & 25.16 & 27.70 & 26.44 \\
\hline \multirow{4}{*}{ TOTAL } & $\mathrm{N}$ & 41 & 40 & 81 \\
\hline & $\Sigma X$ & 1202 & 1093 & 2295 \\
\hline & $\Sigma \mathrm{X}^{2}$ & 36142 & 30243 & 66385 \\
\hline & $\overline{\boldsymbol{X}}$ & 28.86 & 27.22 & 28.05 \\
\hline
\end{tabular}

Pengujian hipotesis dilakukan menggunakan teknik analisis varians (ANAVA).

Hasil perhitungan ANAVA seperti yang ditunjukkan dalam Tabel 3, yaitu Rangkuman analisis faktorial $2 \times 2$. 
Tabel 3. Rangkuman Analisis Faktorial 2x2

\begin{tabular}{lcccccc}
\hline \multicolumn{1}{c}{ Sumber Varians } & JK & dk & RJK & $\mathbf{F}_{\text {hitung }}$ & $\mathbf{F}_{\text {tabel }}$ & Kesimpulan \\
\hline Strategi Pembelajaran & 80,35 & 1 & 80,35 & 8,61 & 3.96 & Signifikan \\
Gaya Belajar & 256,4 & 1 & 256,4 & 27,49 & 3.96 & Signifikan \\
Interaksi & 1023 & 1 & 1023 & 109,7 & 3.96 & Signifikan \\
\hline Antar Kelompok & 641,9 & 3 & 214 & & & \\
Dalam Kelompk & 718,1 & 77 & 9,326 & & & \\
\hline Total & $\mathbf{1 3 6 0}$ & $\mathbf{8 0}$ & & & & \\
\hline
\end{tabular}

Berdasarkan rangkuman di atas maka akan dirinci pengujian hipotesis sebagai berikut:

\section{Hipotesis Pertama.}

Pengujian hipotesis pertama yang menyatakan hasil belajar Matematika siswa yang dibelajarkan dengan strategi pembelajaran kooperatif TGT lebih tinggi daripada hasil belajar siswa yang diajarkan dengan strategi ekspositori, Hipotesis statistiknya adalah:
Ho : $\mu_{\mathrm{A} 1} \leq \mu_{\mathrm{A} 2}$
$\mathrm{Ha}: \mu_{\mathrm{A} 1}>\mu_{\mathrm{A} 2}$

Keterangan:

$\begin{array}{rlr}\mu_{\mathrm{A} 1}= & \text { Rata-rata hasil Belajar } & \text { Matematika } \\ & \text { Antara Siswa Yang Dibelajarkan } \\ & \text { Dengan Menggunakan } \quad \text { Strategi } \\ & \text { Pembelajaran kooperatif TGT } \\ \mu_{\mathrm{A} 2}= & \text { Rata-Rata Hasil Belajar Matematika } \\ & \text { Dibelajarkan Dengan Strategi } \\ & \text { Pembelajaran Ekspositori. } \\ & \text { Berdasarkan perhitungan ANAVA }\end{array}$
faktorial $2 \times 2$ diperoleh $F_{\text {hitung }}=44,7$ sedangkan nilai $\mathrm{F}_{\text {tabel }}=3,96$ untuk dk $(1,77)$ dan taraf nyata $\alpha=0,05$. Ternyata nilai $F_{\text {hitung }}=44,7>3,96$ $=\mathrm{F}_{\text {tabel }}$ sehingga pengujian hipotesis menolak Ho dan menerima Ha. Dengan demikian dapat ditarik kesimpulan bahwa hasil belajar Matematika siswa yang dibelajarkan dengan Strategi pembelajaran kooperatif TGT lebih tinggi dibanding dengan strategi ekspositori dapat diterima dan terbukti secara empirik. Hal ini juga terlihat dari rata-rata hasil belajar Matematika yang dibelajarkan dengan Strategi pembelajaran kooperatif TGT lebih tinggi dari hasil belajar Matematika yang dibelajarkan dengan strategi ekspositori.

\section{Hipotesis Kedua.}

Pengujian hipotesis kedua yang menyatakan: hasil belajar Matematika siswa yang memiliki gaya belajar kinestetik lebih tinggi daripada siswa yang memiliki gaya belajar visual. Hipotesis statistiknya adalah:

Ho : $\mu_{\mathrm{B} 1} \leq \mu_{\mathrm{B} 2}$
$\mathrm{Ha}: \mu_{\mathrm{B} 1}>\mu_{\mathrm{B} 2}$

Keterangan:

$\mu_{\mathrm{B} 1} \quad=$ Rata- rata hasil belajar Matematika antara siswa yang memiliki gaya belajar kinestetik

$\mu_{\mathrm{B} 2}=$ Rata- rata hasil belajar Matematika antara siswa yang memiliki gaya belajar visual.

Berdasarkan perhitungan ANAVA faktorial $2 \times 2$ diperoleh $\mathrm{F}_{\text {hitung }}=21.3$ sedangkan nilai $\mathrm{F}_{\text {tabel }}=3,96$ untuk dk $(1,77)$ dan taraf nyata $\alpha=0,05$. Ternyata nilai $F_{\text {hitung }}=21,3>3,96=$ $\mathrm{F}_{\text {tabel }}$ sehingga pengujian hipotesis menolak Ho dan menerima Ha. Dengan demikian dapat ditarik kesimpulan bahwa hasil belajar Matematika siswa yang memiliki gaya belajar kinestetik lebih tinggi dibanding siswa yang memiliki gaya belajar visual dapat diterima dan terbukti secara empirik. Hal ini juga terlihat dari rata-rata hasil belajar Matematika yang dibelajarkan dengan Strategi pembelajaran kooperatif TGT lebih tinggi dari hasil belajar Matematika yang dibelajarkan dengan strategi ekspositori.

\section{Hipotesis Ketiga.}

Pengujian hipotesis yang ketiga yaitu: terdapat interaksi antara strategi pembelajaran dan gaya belajar dalam meningkatkan hasil belajar Matematika.

Ho : $\mathrm{A}$ X $\mathrm{B}=0$

$\mathrm{Ha}: \mathrm{A} X \mathrm{~B} \neq 0$

Keterangan:

$\mathrm{A}=$ Strategi Pembelajaran

$\mathrm{B}=$ Gaya belajar

Berdasarkan perhitungan ANAVA faktorial $2 \times 2$ diperoleh $F_{\text {hitung }}=72,9$ sedangkan nilai $\mathrm{F}_{\text {tabel }}=3,96$ untuk dk $(1,77)$ dan taraf nyata $\alpha=0,05$. Ternyata nilai $F_{\text {hitung }}=72,9>3,96=$ $\mathrm{F}_{\text {tabel }}$ sehingga pengujian hipotesis menolak Ho dan menerima Ha. Dengan demikian dapat ditarik kesimpulan bahwa terdapat interaksi antara strategi pembelajaran dan gaya belajar 
dalam meningkatkan hasil belajar Matematika siswa dapat diterima dan terbukti secara empirik.

Untuk mengetahui interaksi antara strategi pembelajaran dan gaya belajar terhadap hasil belajar Matematika maka dilakukan uji lanjut dengan Uji Scheffe. Rangkuman perhitungan uji Scheffe pada Tabel 4.

Tabel 4. Rangkuman Uji Scheffe

\begin{tabular}{|l|c|c|c|c|}
\hline \multicolumn{2}{|c|}{ Hipotesis Statistik } & F hitung & $\begin{array}{c}\mathbf{F}_{\text {tabel }} \\
\boldsymbol{\alpha = \mathbf { 0 , 0 5 }}\end{array}$ & Ket. \\
\hline Ho: $\mu_{\mathrm{A} 1 \mathrm{~B} 1}=\mu_{\mathrm{A} 2 \mathrm{~B} 1}$ & Ha: $\mu_{\mathrm{A} 1 \mathrm{~B} 1}>\mu_{\mathrm{A} 2 \mathrm{~B} 1}$ & 5,88 & 2,73 & Signifikan \\
\hline Ho: $\mu_{\mathrm{A} 1 \mathrm{~B} 1}=\mu_{\mathrm{A} 1 \mathrm{~B} 2}$ & Ha: $\mu_{\mathrm{A} 1 \mathrm{~B} 1}>\mu_{\mathrm{A} 1 \mathrm{~B} 2}$ & 8,01 & 2,73 & Signifikan \\
\hline Ho: $\mu_{\mathrm{A} 1 \mathrm{~B} 1}=\mu_{\mathrm{A} 2 \mathrm{~B} 2}$ & Ha: $\mu_{\mathrm{A} 1 \mathrm{~B} 1}>\mu_{\mathrm{A} 2 \mathrm{~B} 2}$ & 6,12 & 2,73 & Signifikan \\
\hline Ho: $\mu_{\mathrm{A} 2 \mathrm{~B} 1}=\mu_{\mathrm{A} 1 \mathrm{~B} 2}$ & Ha: $\mu_{\mathrm{A} 2 \mathrm{~B} 1}<\mu_{\mathrm{A} 1 \mathrm{~B} 2}$ & 1,36 & 2,73 & Tidak Signifikan \\
\hline Ho: $\mu_{\mathrm{A} 2 \mathrm{~B} 1}=\mu_{\mathrm{A} 2 \mathrm{~B} 2}$ & Ha: $\mu_{\mathrm{A} 2 \mathrm{~B} 1}<\mu_{\mathrm{A} 2 \mathrm{~B} 2}$ & 0,99 & 2,73 & Tidak Signifikan \\
\hline Ho: $\mu_{\mathrm{A} 1 \mathrm{~B} 2}=\mu_{\mathrm{A} 2 \mathrm{~B} 2}$ & Ha: $\mu_{\mathrm{A} 2 \mathrm{~B} 2}>\mu_{\mathrm{A} 1 \mathrm{~B} 2}$ & 2,80 & 2,73 & Signifikan \\
\hline
\end{tabular}

Berdasarkan Tabel 4. di atas terdapat dua dari enam kombinasi yang dibandingkan menunjukkan hasil yang tidak signifikan, hal ini disebabkan oleh tidak terdapatnya perbedaan yang signifikan antara rata-rata hasil belajar Matematika yang dibelajarkan dengan menggunakan strategi ekspositori berdasarkan gaya belajar kinestetik dan ratarata hasil belajar Matematika yang dibelajarkan dengan Strategi pembelajaran kooperatif TGT berdasarkan gaya belajar visual, dan tidak terdapat perbedaan yang signifikan antara rata-rata hasil belajar Matematika yang dibelajarkan dengan menggunakan strategi ekspositori pada siswa yang memiliki gaya belajar kinestetik dan siswa yang memiliki gaya belajar visual.

Dari hasil uji Scheffe di atas diperoleh simpulan: (1) Rata-rata hasil belajar Matematika siswa yang dibelajarkan dengan Strategi pembelajaran kooperatif TGT berdasarkan gaya belajar kinestetik lebih tinggi dibandingkan dengan rata-rata hasil belajar Matematika siswa yang dibelajarkan dengan strategi ekspositori berdasarkan gaya belajar kinestetik. (2) Ratarata hasil belajar Matematika siswa yang dibelajarkan dengan Strategi pembelajaran kooperatif TGT berdasarkan gaya belajar kinestetik lebih tinggi dibanding dengan ratarata hasil belajar Matematika siswa dengan Strategi pembelajaran kooperatif TGT berdasarkan gaya belajar visual. (3) Rata-rata hasil belajar Matematika siswa yang dibelajarkan dengan Strategi pembelajaran kooperatif TGT berdasarkan gaya belajar kinestetik lebih tinggi dibandingkan dengan rata-rata hasil belajar Matematika siswa yang dibelajarkan dengan strategi ekspositori dan gaya belajar visual. (4) Rata-rata hasil belajar Matematika siswa yang dibelajarkan dengan strategi ekspositori berdasarkan gaya belajar kinestetik lebih rendah dibanding dengan rata-rata hasil belajar Matematika siswa yang dibelajarkan dengan Strategi pembelajaran kooperatif TGT berdasarkan gaya belajar visual. (5) Rata-rata hasil belajar Matematika siswa yang dibelajarkan dengan strategi ekspositori berdasarkan gaya belajar kinestetik lebih rendah dibandingkan dengan rata-rata hasil belajar Matematika siswa yang dibelajarkan dengan strategi ekspositori berdasarkan gaya belajar visual. (6) Rata-rata hasil belajar matemaika siswa dengan strategi pembelajaran ekspositori berdasarkan gaya belajar visual lebih tinggi dibandingkan dengan rata-rata hasil belajar Matematika siswa dengan strategi pembelajaran kooperatif TGT berdasarkan gaya belajar visual.

Hasil pengujian lanjut di atas, menunjukkan adanya interaksi antara strategi pembelajaran dan gaya belajar terhadap hasil belajar Matematika siswa SMK Pharmaca Medan. Interaksi strategi pembelajaran dan gaya belajar dapat ditunjukkan seperti pada Gambar 1. berikut ini: 


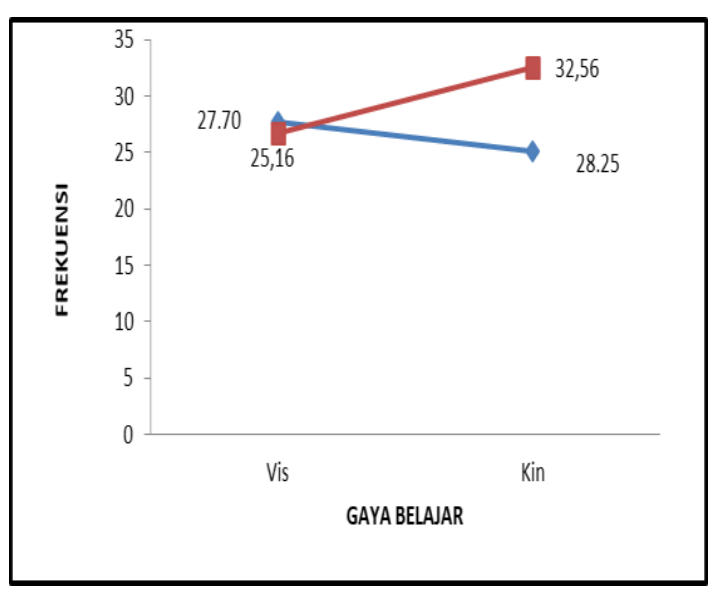

PEMBAHASAN

Perbedaan Hasil Belajar Matematika Antara Siswa Yang Diajarkan Dengan Menggunakan Strategi Pembelajaran Koperatif Tipe TGT Dan Siswa Yang Diajarkan Dengan Menggunakan Strategi Pembelajaran Ekspositori.

Dari hasil pengolahan data yang dilakukan terdapat perbedaan hasil belajar matematika antara peserta didik yang diajarkan dengan strategi pembelajaran Koperatif Tipe TGT dan siswa yang diajarkan dengan strategi ekspositori, hal ini ditunjukkan dari nilai ratarata hasil belajar Matematika siswa yang diajar dengan menggunakan strategi pembelajaran Koperatif Tipe TGT lebih tinggi dibandingkan siswa yang diajar dengan menggunakan strategi pembelajaran ekspositori. Kenyataan ini membuktikan bahwa penggunaan strategi pembelajaran Koperatif Tipe TGT baik dalam meningkatkan pengetahuan peserta didik dalam pembelajaran Matematika.

Dalam Strategi Pembelajaran TGT, para siswa dikelompokkan dalam tim belajar yang terdiri atas empat sampai lima orang yang heterogen. Guru menyampaikan pelajaran, lalu siswa bekerja dalam tim mereka untuk memastikan bahwa semua anggota tim telah menguasai pelajaran (Slavin, 2008). Secara umum, pembelajaran kooperatif tipe TGT memiliki prosedur belajar yang terdiri atas siklus regular dari aktivitas pembelajaran kooperatif. Turnamen dimasukkan sebagai tahapan review setelah siswa bekerja dalam tim.

Dari hasil pengamatan dan diskusi peneliti bersama dengan guru dalam pengkajian strategi pembelajaran pada kelas Koperatif Tipe TGT dan ekspositori, untuk kelas perlakuan strategi pembelajaran Koperatif Tipe TGT untuk tahapan perumusan masalah untuk
Gambar 1. Interaksi Antara Strategi

Pembelajaran Dan Gaya Belajar

Keterangan Gambar 1:

$\begin{array}{cc} & =\text { Strategi Pembelajaran } \\ & \text { Teams } \\ & \text { Games Tournament } \\ & =\text { Strategi Pembelajaran } \\ \text { Kin } & \text { Ekspositori } \\ \text { Vis } & =\text { Gaya Belajar Kinestetik } \\ & =\text { Gaya Belajar Visual }\end{array}$

dipecahkan peserta didik, guru hanya memberi masalah atau soal-soal yang berbeda untuk dicari penyelesaiannya oleh siswa dalam bentuk turnamen (games) sedangkan pada kelas yang diberi perlakuan strategi pembelajaran ekspositori guru lebih banyak menyelesaikan soal-soal yang disajikan dalam contoh. Hal ini dibuktikan dengan lamanya waktu penyajian materi pelajaran pada kelas ekspositori dibandingkan dengan waktu penyajian materi pada kelas Strategi Pembelajaran Koperatif Tipe TGT. Pada kelas Koperatif Tipe TGT siswa akan lebih lama mengingat materi pelajaran yang disajikan guru sehingga pengetahuan tersebut akan lebih bermakna. Hal ini menyebabkan menjadi penyebab tingginya hasil belajar matematika pada kelas Koperatif Tipe TGT.

Pada tahapan penetapan jawaban sementara atau pengajuan hipotesis, dari hasil pengamatan dan diskusi peneliti beserta guru yang dilibatkan tampak bahwa siswa pada kelas Koperatif Tipe TGT menemukan langsung jawaban secara tim artinya semua perntanyaan didiskusi bersama didalam kelompok dan pembuktian atas tugas-tugas yang diberikan guru untuk di tes kan dalam bentuk pertandingan antar kelompok hingga kelompok akan mencoba memahami sebanyak mungkin dan mencoba bekonsentrasi dengan fokus agar setiap perntanyaan yang dilontarkan guru dapat dijawab oleh tim atau kelompok. Sedangkan pada kelas ekspositori, siswa cenderung pasif dan malu-malu untuk bertanya. Hal ini menjadi penyebab lebih tingginya hasil belajar Matematika pada kelas Koperatif Tipe TGT

Pada tahapan peserta didik mencari informasi, data dan fakta yang diperlukan untuk menjawab atau memecahkan masalah dan menguji hipotesis. Dari hasil pengamatan dan diskusi peneliti beserta guru yang dilibatkan tampak bahwa siswa pada kelas Koperatif Tipe 
TGT cenderung lebih aktif mencari informasi bagaimana cara atau langkah untuk menyelesaikan soal-soal yang diberikan guru dan mereka lebih berani bertanya kepada guru jika kesulitan dalam memecahkan masalah matematika. Sedangkan pada kelas ekspositori, tampak siswa lebih cenderung pasif, siswa lebih dominan dibimbing oleh guru tentang langkahlangkah bagaimana menyelesaikan soal matematika dan jika ada kesulitan hanya beberapa orang saja yang berani bertanya dan selebihnya kurang memberikan respon. Hal ini menjadi penyebab tingginya hasil belajar Matematika pada kelas Koperatif Tipe TGT.

Pada tahapan menarik kesimpulan dari jawaban atau generalisasi. Dari hasil pengamatan dan diskusi peneliti beserta guru yang dilibatkan tampak bahwa siswa pada kelas Koperatif Tipe TGT cenderung lebih cepat dalam memahami materi pelajaran yang disajikan dalam bentuk contoh soal dan mereka dapat lebih mudah memahami bagaimana menarik kesimpulan dari materi secara keseluruhan. Sedangkan pada kelas ekspositori siswa lebih cenderung diam, mendengar dan mencatat materi pelajaran yang diberikan oleh guru dan kesimpulan dari materi pelajaran juga atas kesimpulan yang diperoleh atas arahan guru. Peneliti menyimpulkan ini sebagai penyebab lebih tingginya hasil belajar matematika pada kelas yang diberi perlakuan strategi pembelajaran Koperatif Tipe TGT.

Pada tahapan aplikasi kesimpulan atau generalisasi dalam situasi baru. Dari hasil pengamatan dan diskusi peneliti beserta guru yang dilibatkan tampak bahwa siswa pada kelas Koperatif Tipe TGT dapat mengaplikasikan kesimpulan dari materi yang dipelajari lebih tinggi dari siswa pada kelas ekspositori dan ini terlihat dari mereka dapat menyelesaikan soalsoal dalam tingkat kesukaran yang berbeda. Peneliti menyimpulkan pada kelas yang diberi strategi pembelajaran Koperatif Tipe TGT presentase yang dilakukan kelompok Koperatif Tipe TGT terhadap hasil temuan siswa didalam kelompok adalah kesimpulan terhadap hasil diskusi temuan siswa, Sedangkan pada kelas ekspositori kesimpulan lebih cenderung dilakukan oleh guru dengan hanya memberi penekanan pada tujuan pelajaran yang akan dicapai setelah selesai melaksanakan pembelajaran. Hal ini menyebabkan tingginya hasil belajar matematika pada kelas Koperatif Tipe TGT.
Dari pembahasan di atas, sangat sesuai dengan hasil penelitian yang diperoleh bahwa hasil belajar siswa yang diajar dengan strategi pembelajaran Koperatif Tipe TGT lebih tinggi daripada hasil belajar siswa yang diajar dengan strategi pembelajaran ekspositori.

\section{Perbedaan Hasil Belajar Matematika Antara Siswa Yang Memiliki Gaya Belajar Kinestik dengan Gaya belajar visual.}

Hasil penelitian menunjukkan bahwa rata-rata hasil belajar Matematika siswa yang memiliki gaya belajar kinestetik lebih tinggi daripada hasil belajar Matematika siswa yang memiliki gaya belajar visual. Selanjutnya dalam penelitiann ini juga terbukti bahwa hasil belajar matematika siswa yang memiliki gaya belajar kinestetik yang diajar dengan Strategi pembelajaran Koperatif Tipe TGT lebih tinggi daripada hasil belajar Matematika siswa yang diajar dengan Strategi pembelajaran ekspositori. Hal ini mengindikasikan bahwa siswa yang mempunyai gaya belajar kinestetik lebih mampu memahami bahan pelajaran Matematika dengan cara Koperatif Tipe TGT dibandingkan siswa yang mempunyai gaya belajar visual. Penelitian ini juga rnembuktikan bahwa siswa yang memiliki gaya belajar kinestetik lebih cocok diajar dengan menggunakan Strategi Koperatif Tipe TGT. Pembelajaran dengan Strategi Koperatif Tipe TGT sangat tepat dibandingkan Strategi pembelajaran ekspositori untuk diterapkan pada siswa yang memiliki gaya belajar kinestetik. Dalam pembelajaran Matematika, siswa yang memiliki gaya belajar kinestetik biasanya akan tertantang untuk mengelola informasi yang diterima secara kreatif, dan sistematis. Sebagai pemikir realistik, siswa yang memiliki gaya belajar konkrit akan terbiasa melakukan kegiatankegiatan berpikir secara sistematis dan ilmiah. Dengan demikian siswa yang selalu melatih dirinya terus menerus akan dapat menemukan prosedur berpikir secara logis dan di dalam memecahkan persoalan-persoalan belajar, termasuk pada pelajaran menggambar teknik .

Siswa yang memiliki gaya belajar kinestetik adalah siswa yang selalu dapat dengan mudah mengingat informasi yang diberikan dengan cara pendekatan pembelajaran kongkrit. Siswa kinestetik akan sangat terbantu dalam belajar jika mereka dapat dilibatkan secara langsung dalam proses tersebut sehingga memberikan pemahaman dan penguatan memori kepada siswa itu sendiri. Dalam strategi 
Koperatif Tipe TGT siswa yang memiliki gaya belajar kinestetik yang pada umumnya memiliki karakteristik tidak dapat diam terlalu lama dalam mendengarkan pelajaran, akan dibawa secara langsung untuk terilibat aktif dalam rnengeksplorasi materi pelajaran yang mereka terima strategi belajar sekaligus rnenyerap informasi dalam bentuk gambar dan tulisan yang mereka buat sendiri.

Sebaliknya, bagi siswa yang bergaya belajar visual, yang memegang peranan penting adalah mata ( visual ). Siswa yang mempunyai gaya belajar visual harus melihat bahasa tubuh dan ekspresi muka gurunya untuk mengerti materi pelajaran. Mereka cenderung untuk duduk di depan agar dapat melihat dengan jelas. Mereka berpikir menggunakan gambar-gambar di otak mereka dan belajar lebih cepat dengan menggunakan tampilan-tampilan visual, seperti diagram, buku pelajaran bergambar, dan video.

\section{Interaksi antara Strategi Pembelajaran dengan Gaya Belajar terhadap Hasil Belajar Matematika Siswa}

Temuan penelitian menunjukkan bahwa terdapat interaksi antara strategi pembelajaran dan Gaya Belajar terhadap hasil belajar matematika. Siswa yang memiliki Gaya belajar Kinestetik memiliki hasil belajar yang lebih tinggi daripada siswa yang memiliki Gaya belajar visual yang diajar dengan menggunakan strategi pembelajaran Koperatif Tipe TGT, demikian pula halnya dengan siswa yang memiliki Gaya belajar visual memiliki hasil belajar yang lebih tinggi daripada siswa yang memiliki Gaya belajar Kinestetik pada kelas yang diberi strategi pembelajaran ekspositori. Hal ini mengindikasikan adanya interaksi antara penggunaan strategi pembelajaran dengan gaya belajar terhadap hasil belajar matematika siswa.

Pembelajaran kooperatif tipe TGT adalah salah satu strategi pembelajaran kooperatif yang mudah diterapkan melibatkan aktivitas seluruh siswa tanpa harus ada perbedaan status, melibatkan peran siswa sebagai tutor sebaya dan mengandung unsur permainan dan reinforcement. Aktivitas belajar dengan permainan yang dirancang dalam pembelajaran kooperatif tipe TGT memungkinkan siswa dapat belajar lebih rileks disamping menumbuhkan tanggungjawab, kerjasama, persaingan sehat dan keterlibatan belajar, sehingga melatih keterampilan kognitif siswa untuk menemukan dan memecahkan masalah tanpa pertolongan orang lain. Dalam strategi pembelajaran Koperatif Tipe TGT sangat diharapkan keterlibatan siswa secara aktif agar dapat memecahkan masalah baik secara mandiri maupun secara bersama-sama dalam diskusi secara klasikal dan mampu berpikir bebas.

Siswa dengan tipe Kinestetik lebih menyukai proyek terapan. Lakon pendek dan lucu terbukti dapat membantu siswa kinestetik dapat belajar melalui gerakan, dan paling baik menghafal informasi dengan mengasosiasikan gerakan dengan setiap fakta. Tunjukkan caranya kepada mereka. Banyak siswa kinestetik menjauhkan diri dari bangku, mereka lebih suka duduk dilantai dan menyebarkan pekerjaan disekeliling mereka. individu yang memiliki kemampuan belajar kinestetik yang baik ditandai dengan ciri-ciri perilaku sebagai berikut: berbicara dengan perlahan, menanggapi perhatian fisik, menyentuh orang lain untuk mendapatkan perhatian mereka, berdiri dekat ketika sedang berbicara dengan orang lain, belajar melalui praktek langsung atau memanipulasi, menghafalkan sesuatu dengan cara berjalan atau melihat langsung, menggunakan jari-jari untuk menunjuk kata yang dibaca ketika sedang membaca, banyak menggunakan bahasa tubuh (non verbal), tidak dapat duduk diam disuatu tempat untuk waktu yang lama, sulit membaca peta kecuali ia memang pernah ketempat tersebut, menggunakan kata-kata yang aksi, pada umumnya tulisannya jelek, menyukai kegiatan atau permainan yang menyibukkan (secara fisik) dan ingin melakukan segala sesuatu. Dengan demikian siswa yang memiliki Gaya belajar Kinestetik sangat sesuai jika diberi pembelajaran Koperatif Tipe TGT.

Gaya belajar visual adalah gaya belajar seseorang yang cenderung menggunakan jalur penglihatannya dalam menerima dan memasukkan informasi kedalam otak, atau secara umum tipe gaya belajar visual melakukan aktivitas belajar melalui bubungan visual. Siswa visual perlu didorong untuk membuat banyak simbol dan gambar dalam catatan mereka. Dalam matematika dan ilmu pengetahuan, tabel dan grafik juga akan sangat membantu dalam memperdalam pemahaman mereka. Dengan demikian siswa yang memiliki Gaya belajar visualsangat sesuai dibelajarkan dengan strategi ekspositori.

Strategi pembelajaran ekspositori yang berfokus pada guru dan mengharapkan siswa untuk mendengar dan mencatat materi pelajaran 
sesuai dengan karakteristik siswa yang memiliki gaya belajar visual. Hal ini mengakibatkan hasil belajar matematika siswa yang memiliki Gaya belajar Kinestetik dibelajarkan dengan strategi Koperatif Tipe TGT lebih tinggi daripada hasil belajar matematika siswa yang memiliki Gaya belajar visual yang dibelajarkan dengan strategi Koperatif Tipe TGT dan hasil belajar siswa yang memiliki Gaya belajar visual yang dibelajarkan dengan strategi pembelajaran ekspositori lebih tinggi daripada siswa yang memiliki Gaya belajar Kinestetik yang dibelajarkan dengan strategi ekspositori.

\section{PENUTUP}

Berdasarkan hasil penelitian dan pembahasan yang dikemukakan sebelumya, maka dapat disimpulkan bahwa :

1. Hasil belajar matematika siswa yang diajarkan dengan strategi koperatif tipe TGT lebih tinggi dibandingkan dengan hasil belajar matematika siswa yang diajarkan dengan strategi pembelajaran ekspositori.

2. Hasil belajar matematika siswa yang memiliki gaya belajar kinestetik lebih tinggi daripada siswa yang memiliki gaya belajar visual.

3. Terdapat interaksi antara strategi pembelajaran dan gaya belajar yang memberikan perbedaan pengaruh terhadap hasil belajar matematika siswa. Perbedaan pengaruh tersebut adalah :

a. Hasil belajar matematika siswa dengan gaya belajar kinestetik yang diajar dengan strategi kooperatif TGT lebih tinggi daripada hasil belajar siswa dengan strategi pembelajaran ekspositori.

b. Hasil belajar matematika siswa dengan gaya belajar kinestetik yang diajar dengan Strategi kooperatif TGT lebih tinggi daripada hasil belajar siswa dengan gaya belajar visual yang diajar dengan strategi pembelajaran ekspositori.

c. Hasil belajar matematika siswa dengan gaya belajar kinestetik yang diajar dengan strategi pembelajaran ekspositori lebih rendah daripada hasil belajar siswa dengan gaya belajar visual yang diajar dengan strategi pembelajaran ekspositori. d. Hasil belajar matematika siswa dengan gaya belajar visual yang diajar dengan strategi kooperatif TGT lebih rendah daripada hasil belajar siswa dengan gaya belajar visual yang diajar dengan strategi pembelajaran ekspositori.

e. Hasil belajar matematika siswa dengan Strategi kooperatif TGT lebih tinggi daripada hasil belajar siswa yang diajar dengan strategi pembelajaran ekspositori.

f. Hasil belajar matematika siswa dengan gaya belajar kinestetik lebih tinggi daripada hasil belajar siswa dengan kemampuan gaya belajar visual.

\section{DAFTAR PUSTAKA}

Ansari, B.I ( 2009 ). Komunikasi Matematik Konsep dan Aplikasi. Yayasan Pena : Banda

Anzwar, S. ( 1986). Realibilitas dan Validitas Interprestasi dan Komputasi.

Yogyakarta : Liberty (2008). Penyusunan skala psikiologi. Yogyakarta : Pustaka Pelajar.

Arikunto,S.(1998).Manajemen Penelitian.Jakarta :PT.Rineka Cipta

Bloom, B.S, et-al. 1997. Handbook on information and Summative evaluation of student learning. Chiacago Publishing. Mc. Grew Hijji. Inc.

Buthcher, C. A., dan Kunig, C. R. 1974. Method and Materials for Secondary Psycal Education. St. Louis : The CV. Moosby Company

DePorter (2004). Quantum Learning.Bandung : Penerbit Kaifa

DePorter (2004).Quantum Teaching.Bandung : Penerbit Kaifa

Dick,W \& Carey,L(2005).The systematic Design of Instruction.Glenview Illinois:Scot,Foresman and Company.

Gagne, R.M \& Briggs, L.J. (1974). Principle of Instructional Design. Second Edition. New York : Holt, Rinerhart and Winston Inc.

Ginnis, P. (2008). Trik dan Taktik Mengajar Strategi Meningkatkan Pencapaian Mengajar di Kelas. Alis Bahasa oleh Wasi Dewanto. Jakarta : Indeks

Gordon Dryden,(2003) The Learning Revolution.Bandung : Penerbit Kaifa

Gulo. 2001. Strategi Belajar Mengajar. Jakarta: Gremedia widiasarana Indonesia. 
Gunawan. 2004. Born to be a Genius. Jakarta: Gramedia Pustaka Utama

Hall, G.E, Quinn, L.F \& Gollnick, D.M (2008). Mengajar Dengan Senang Menciptakan perbedaan dalam Pembelajaran Siswa. Jakarta : Indeks

Hamalik, O. (2001). Proses Belajar Mengajar. Jakarta : Bumi Aksara.

Hamid, A. (2007) Teori Belajar dan Pembelajaran. Medan : Tim Kreatif pascasarjana Unimed.

Hasan, S.H. (1996). Pendidikan Ilmu-Ilmu Sosisal. Bandung : FIPS IKIP Bandung

Heinich, RE. 1996. Instructional Media and Technologies for Learning $3 * i$ New Jersey : Enggle Wood Prentice Hall.

Johnson, D.W. \& Johnson, R.T., 1991, Learning Together and Alone: Cooperative, Competitive, and Individualistic Learning (3rd edition), Upper Saddle River, NJ: Prentice-Hall.

Joyce, B. \& Weil, M. 1986. Model of Teaching. New Jersey: Prentice-Hall, inc.

Kincaid, D.L. \& Schramm, W. (1977). AzasAzas Komunikasi Antar Manusia. Terjemah oleh Agus Setiadi. Jakarta : LP3ES

Keefe (1987).Learning styles.Theory and Practice,Reston. Virginia:National Association of Secondary School Principles(NASSP)

Lie, A. (2008). Cooperative Learning Mempraktekkan Cooperative Learning di Ruang-Ruang Kelas. Jakarta : Grasindo

Littlejohn, S. W. 1999. Theories of Human Communication Sixth Editon. New Mexico : Wadsworth Publishing Company

Majid, A. (2008). Peencanaan Pembelajaran Mengembangkan Standart kompetensi Guru. Bandung : Remaja Rosdakarya

Miarso, Y. (2004).Menyemai Benih Teknologi Pendidikan,Jakarta:Prenada Media
Mulyana, D. (2007). Ilmu Komunikasi Suatu Pengantar. Bandung : Remaja Rosdakarya

Nur dkk.(2000). Pembelajaran Kooperatif. Surabaya: UNESA UNIVERSITY PRESS. Nurhadi. 2003. Contekstual Teaching and Learning. Jakarta: Bumi Aksara.

Ruseffendi, ET (1980). common textbook. Sadirman, 2003. Interaksi dan motivasi Belajar mengajar. Jakarta: Rajawali pers Sagala, 2008. Konsep dan Makna Pembelajaran. Bandung: Alfabeta.

Sanjaya, W. (2008). Strategi Pembelajaran Berorientasi Standar Proses Pendidikan. Jakarta : Kencana

Severin, W.J.\& Tankard, J.W.Jr. (2008). Teori Komunikasi Sejarah, Metode, dan Terapan di dalam Media Massa. Edisi Kelima. Kencana

Slameto. (2003). Belajar dan Faktor-Faktor yang Mempengaruhinya. Jakarta : Rineka Cipta.

Slavin, R.E. (1983). Cooperative Learning. Maryland : John Hopkins University

Sumadi Suryabrata. 2002. Psikologi Pendidikan. Jakarta: RajaGrafindo Persada

Supatmono, C. (2009). Matematika Asyik, Asyik Mengajarnya Asyik Belajarnya. Jakarta : Grasindo

Sudjana. 2002. Metode Statistika. Bandung : Tarsindo

Sukmadinata(1992).Teori Belajar Untuk Pembelajaran Matematika,Jakarta:PSG Depdikbud

Suparman,Atwi(1997).Desain Instruksional,Jakarta:PAU-PPAI-UI

Uno,H.B. (2008). Perencanaan Pembelajaran. Jakarta : Bumi Aksara

Winkel,W.S(2007).Psikologi Pengajaran.Yogyakarta:Media Abadi 